\title{
On the role of the property tax in financing local expenditure: the case of Italy
}

\author{
Ernesto Longobardi
}

SERIES Working PAPERS N. 06/2015

SERIES sono pubblicati a cura del Dipartimento di Scienze economiche e metodi matematici dell'Università degli Studi di Bari "Aldo Moro". I lavori riflettono esclusivamente le opinioni degli autori e non impegnano la responsabilità del Dipartimento. SERIES vogliono promuovere la circolazione di studi ancora preliminari e incompleti, per suscitare commenti critici e suggerimenti. Si richiede di tener conto della natura provvisoria dei lavori per eventuali citazioni o per ogni altro uso.
SERIES are published under the auspices of the Department of Economics of the University of Bari. Any opinions expressed here are those of the authors and not those of the Department. Often SERIES divulge preliminary or incomplete work, circulated to favor discussion and comment. Citation and use of these paper should consider their provisional character. 


\title{
On the role of the property tax in financing local expenditure: the case of Italy
}

\author{
Ernesto Longobardi ${ }^{*}$
}

September 13, 2013

\begin{abstract}
The paper discusses some issues concerning the local property tax in the light of the Italian experience. The main developments concerning the municipal property tax in Italy, since its introduction and until the most recent events, are briefly described. Then three main issues regarding the local property tax are addressed. First, the question whether there is any economic rationality in exempting owner occupied houses, a theme that has been central in the Italian debate and in the political arena in the last years; second, the long debated issue of whether the local property tax is a good benefit tax; and, finally, the possibility that a "residence tax", levied on the occupant of the dwelling, would represent a better opportunity for implementing the benefit principle than the traditional property tax levied on the owners.
\end{abstract}

Key words: property tax, benefit principle, tax reform, political economy

JEL codes: H2, H71, H77, D7

Paper presented at The Copenhagen Workshop 2013, Interaction between local expenditure responsibilities and local tax policy, Copenhagen, $12^{\text {th }}$ and $13^{\text {th }}$ September 2013 , organized by The Korea Institute of Public Finance and the Danish Ministry for Economic Affairs and the Interior. The author wishes to thank Alberto Zanardi and the participants to the Copenhagen Workshop, in particular Maarten A. Allers and Richard M. Bird, for their very helpful comments.

\footnotetext{
*University of Bari, Italy ernesto.longobardi@uniba.it
} 


\section{Introduction}

At present in Italy the main issue of local tax policy concerns the role and the design of the property tax at the municipal level. As in many other countries, the property tax is the main source of revenue for municipalities. The ICI (Imposta comunale sugli immobili) was introduced in 1992/1993. In the 2008 electoral campaign Berlusconi promised to abolish ICl on owner-occupied houses and this was decisive in determining his party's victory. The new government honoured the promise. Municipalities were compensated for the loss of revenue by increasing the grants from the central State. In 2012, within the program of financial consolidation of the Monti's government, the tax was reformed: the new IMU (Imposta municipale) was again extended to owner-occupied houses and the burden of the tax was remarkably increased, augmenting the rate and the cadastral rents. In 2013 election the story was repeated. Again Berlusconi's party promised to abolish the tax on owner-occupied houses. The new Letta's government, currently in power, which is supported by a large coalition including the centre-left party (PD) and the Berlusconi's party (PDL), is studying a reform of the municipal property tax, trying to conciliate the different views of the two main parties. The design, which has been announced, is inspired to the model of the residence tax, applied in the U.K. with the Council Tax and in France with the Taxe d'habitation, according to which the tax is due by persons living in the house even if they are not the owners.

The first part of the paper ( $\S 1-3)$ summarizes the main developments concerning the municipal property tax in Italy since its introduction until the most recent events. In the second part three main issues regarding the local property tax are discussed in the light of the Italian case. The question whether there is any economic rationality in exempting main residences from a local property tax is addressed first (§ 4); the long debated issue of whether the local property tax is a good benefit tax is then considered ( $\S 5$ ); finally the possibility is discussed that a residence tax would represent a better opportunity for implementing the benefit principle than the traditional property tax

\section{From ICi to IMU and beyond: the Italian story of the municipal property tax}

1. Currently in Italy the role and the nature of the municipal property tax represents the main issue of local taxation. As in many other countries the property tax (PT) is a major source of revenue for municipalities. Table 1 shows that in 2011 the yield from the municipal tax on real estate (Imposta comunale sugli immobili, ICI) was close to 10 billions of euro, about $41 \%$ of the total tax revenue and around $18 \%$ of the total revenue in current account. 


\begin{tabular}{|l|r|r|}
\hline \multicolumn{3}{|c|}{ Table 1 - Revenues of Italian Municipalities 2011 } \\
\hline & $\begin{array}{c}\text { millions of } \\
\text { euro }\end{array}$ & \multicolumn{1}{c|}{$\%$} \\
\hline Taxes & $\mathbf{2 3 . 8 2 8}$ & $\mathbf{4 4 , 2} \%$ \\
\hline Municipal property tax (ICI) & 9.816 & $41,2 \%$ \\
\hline Waste tax & 6.813 & $28,6 \%$ \\
\hline Municipal surcharge on IRPEF (PIT) & 3.225 & $13,5 \%$ \\
\hline Other taxes & 3.974 & $16,7 \%$ \\
\hline & & \\
\hline Tariffs, user charges and fees & $\mathbf{8 . 8 9 3}$ & $\mathbf{1 6 , 5 \%}$ \\
\hline \multicolumn{2}{|c|}{} & \\
\hline Transfers & $\mathbf{2 1 . 1 3 0}$ & $\mathbf{3 9 , 2} \%$ \\
\hline From the State & 13.757 & $65,1 \%$ \\
\hline From Regions & 6.476 & $30,7 \%$ \\
\hline Others & 896 & $4,2 \%$ \\
\hline \multicolumn{2}{|c|}{} & \\
\hline Total & $\mathbf{5 3 . 8 5 0}$ & $\mathbf{1 0 0 , 0 \%}$ \\
\hline \multicolumn{2}{|c|}{} & \\
\hline Source: Rearranged from Istat (Italian National Institute of Statistics) \\
\hline
\end{tabular}

The municipal PT was firstly introduced on a temporary basis in 1992, within a package of fiscal measures undertaken in order to face a deep financial and currency crisis. The tax was definitively confirmed the following year (1993). All forms of real estate were included in the tax base: residential, industrial and commercial buildings, and land both for agriculture and residential purposes. The tax was applied to the cadastral values of the estate. The City council was empowered of setting the tax rate within the range $0.4 \%-0.7 \%$.

In the 2008 electoral campaign Berlusconi promised to abolish the $\mathrm{ICl}$ on owner-occupied houses and his commitment resulted decisive in determining the electoral success of his centre-right party. The new government honoured the promise excluding main residences from the ICl's tax base. The loss of revenue for municipalities, about 3.5 billions of euro, was compensated increasing the grants from the State. Surprisingly enough the North-League Party, which was in the governmental majority, and whose program was characterized by a strong autonomist view of local powers, did not take position against a measure that was going in the opposite direction, that one of strengthening the central power in taxation. Even the municipalities did not oppose to the reform, confirming their reluctance to exercise an effective autonomous tax power over their citizens.

The exemption of owner-occupied dwellings lasted for four tax years, from 2008 to 2011. In the fall 2011 the political crisis, connected with the financial crisis that hit the country, brought about a "technical" government headed by Professor Mario Monti. Within a large package of fiscal consolidation measures the local PT, renamed IMU (Imposta municipale), was extensively reformed enhancing its role in the tax system.

It is worth noting that both the introduction of the local PT in 1992-93 and its strengthening in 2012 were decided in connection with a financial crisis. In both cases one of the effects of the crisis was to augment the general government fiscal capacity and represented the occasion to introduce reforms of local taxation. These reforms had been discussed and prepared for a long time. The difficulties encountered in normal times in obtaining the necessary level of consensus among political parties and the representatives of the different level of government were overcome in the exceptional situation. 
2. The Monti government's modification of the municipal PT was partially an anticipation of a measure already approved by the preceding Berlusconi government, within the framework of the s.c. "fiscal federalism" reform started in 2009. The main innovation of this latter design was the melting up of the PT with the personal income tax (PIT). The PIT over figurative (cadastral) income deriving from non-rented residences was abolished and the tax rate of the PT was correspondingly increased. This reform should have been implemented in 2014.

The Monti government anticipated the introduction of IMU to 2012 and, at the same time, modified the design of the tax and provided for a substantial increase in its overall burden. The main innovation in the tax structure was the reintroduction of owner-occupied residences into the tax base. The basic tax rate was settled at $0.76 \%$, allowing the municipalities the possibility to change it within the range $+/-0.3 \%$. The basic rate for main houses was instead established at $0.4 \%$ with a range $+/-0.2$ of possible variations.

The increase in the incidence of the tax was also realised augmenting the cadastral rents through the application of different multiplicative coefficients to the various categories of real estate. All together these measures have produced an enormous increase in the yield of the municipal PT: from 9.8 billion of ICI 2011 to 23.8 billion of IMU 2012, an increase of more than $240 \%$. However, the larger amount of revenue was not attributed entirely to the municipalities. Instead a peculiar form of tax co-habitation was established. The State was entitled of a share of the revenue, equal to $1 / 2$ of the yield originating from the standard rate, excluding main residences from the computation.

Table 2 reports the composition of the revenue produced by IMU in 2012, distinguishing the municipal and the State shares and the part of revenue collected at the standard rate from the one attributable to fiscal effort.

\begin{tabular}{|l|r|r|r|}
\hline Table 2 - Imu revenue 2012 (millions of euro) \\
\hline & \multicolumn{1}{|c|}{ Total } & at standard rate & from fiscal effort \\
\hline & & & \\
\hline Main residences & & & \\
\hline Other estate (municipal component) & 4.033 & 3.383 & 649 \\
\hline Other estate (State component) & 11.682 & 8.869 & 0 \\
\hline & 8.077 & 8.077 & $\mathbf{3 . 4 6 3}$ \\
\hline Total & & & $\mathbf{2 0 . 3 2 9}$ \\
\hline \multicolumn{2}{|l|}{} \\
\hline Source: Ministero dell'Economia e delle Finanze - Dipartimento delle Finanze (2013) \\
\hline
\end{tabular}

Apparently the split of the revenue between the State and the municipalities responded to a logic of tax sharing, with the peculiarity that usually a tax of a given level of government is shared with a lower government, while in this case it was the other way round, a local tax being shared with the central government.

Rather scholars in tax law have identified the existence of two distinct taxes, a State tax and a municipal one, which have been twined only for assessment and collection purposes.

On another side, economists have pointed out a number of shortcomings of this arrangement. The coexistence of two levies, belonging to the competence of two different levels of government, compromises accountability and the role that the PT could in principle play as a price for local public services. 
Moreover, the concrete mechanism envisaged in order to split the revenue into its two components creates a disincentive for the municipalities to exercise their autonomous power of reducing the tax rate. This is because, considering that it is necessary to guarantee to the State half of the revenue calculated at the standard rate of $0.76 \%$, irrespectively of the actual rate established by the municipal council, any percentage reduction in the rate $(x \%)$ would result in a double $(2 x \%)$ reduction in the revenue accruing to the municipal budget.

The IMU introduced by the Monti government was the object of several other criticisms. The choice to abolish the PIT due on imputed incomes from real estate and to compensate the loss of revenue by increasing the overall incidence of the PT, created a discrimination against two categories of real estate. Because located dwellings are taxed on the basis of actual, not imputed, income, they could not benefit of the PIT relief, while being hit by the increase in the effective tax rate of IMU. The buildings registered as assets in the budget sheets of firms, either as instrumental assets or just as a component of the endowment of the firm, were also excluded from the PIT relief, because they do not produce real estate income, but contribute to generate business income.

The main improvement, generally recognised to the Monti's reform of the local PT, was the extension of the tax to owner-occupied houses, whose exemption in 2008 had no reasonable economic justification and was decided only in order to gain political consensus in the electoral competition. This conquest, however, was not destined to last. The story was just about to be repeated.

3. At the end of 2012, with the financial law for 2013, the government modified the State component of IMU. Instead of a half of the tax revenue collectable at the standard rate on the tax base with the exclusion of first residences, the State was entitled of the revenue generated from industrial buildings (the group $D$ of cadastral rents). Again the share of the State had to be calculated at the standard rate. In order to prevent tax competition, municipalities were deprived of the faculty to decrease the rate applied to this type of buildings. They were however left the possibility to increase the rate, maintaining in this way an area of scanty transparency because of the overlapping competences of two level of government.

Things were however just about to change again. In December 2012 the political crisis and the resignations of Monti government brought to new political elections. The IMU issue became the central argument of the electoral competition. Again Berlusconi's party (PDL) promised to remove the tax on owner-occupied houses and again this pledge was a decisive element in preventing the announced electoral victory of the centre-left party (Democratic Party, PD). Neither the centre-left nor the centre-right obtained the absolute majority in both chambers of Parliament necessary to form a government. An agreement between the two main parties produced a large coalition government including both of them.

The new Letta government had the difficult task to try to conciliate the different views of the two parties about the PT. PDL wanted to honour its promise with the electorate, abolishing IMU on main residences. On the other side PD maintained that the tax should have been kept on the basis of two main arguments. From one side, the deletion of the tax on main residences would have undermined the role of IMU as a benefit tax, considered the best instrument to finance local expenditure. On the other side, the abolition of an important part of the PT, more than 4 billions of Euro, would have gone in the opposite direction with respect to what had been repeatedly recommended by the main international organization (EU Commission, IMF, OECD). The receipt 
proposed by these organisations was in fact to move to a more growth friendly tax mix, by reducing taxes on labour and firms and augmenting those on immovable property and on consumption. While maintaining the taxation of owner-occupied houses, the PD wanted to introduce in the tax design some ability-to-pay elements, in the form of a tax credit linked to the income of the taxpayer.

Eventually, very recently (August $31^{\text {st }}, 2013$ ) a decree of the government has deliberate, for the time being, the abolition the first annual IMU payment for 2013 on owner-occupied houses (1/2 of the total liability for these taxpayers). At the same time the government has announced the second 2013 IMU payment, due in December, will also be abolished and that starting with 2014 the IMU will be substituted by a new tax. This new levy, named "service tax", will be modelled looking at the British "council tax" and to the French dual solution of a "taxe foncière" and a "taxe d'habitation". The main point would be to move from a PT, paid by the owners of the house, to a residence tax, paid by the occupants of the house, whether owners or tenants.

This is the end (for the time being) of the story of the Italian municipal PT. What does it tells us? In the following, three main points will be dealt with. The question whether there is any economic rationality in exempting main residences from a local PT will be addressed first. I will then return to the long debated issue of whether the local PT is a good benefit tax. Finally the problem will be considered if a residence tax could represent a better opportunity for implementing the benefit principle than the traditional PT.

\section{Three issues about the local property tax}

4. Is there any good economic reason for exempting main residences from the local PT? If we address the question from the two traditional perspectives of the benefit principle and the abilityto-pay principle, there seems to be no economic rationality in the exemption. On the contrary, from the viewpoint of the benefit principle the exemption would in fact result disruptive, because it would imply the exclusion of the majority of residents from the tax. The residential component of the tax base would be confined to second houses, which in many cases, at least in the Italian context, are owned by non-residents, especially in cities with a touristic vocation. The local PT is a source-based tax. According to the benefit principle the non-resident owners of houses should pay the tax, because in any case they obtain some benefits from the local services. However, nonresidents do not vote. The exportation of the tax would result in local over-spending.

The exemption of owner-occupied houses would be neither justified on the ground of the abilityto-pay principle. Houses, either occupied by their owners or not, are an important component of the wealth of the taxpayer and wealth, like income, is a measure of ability-to-pay.

The only reason for according a special relief to main residences is a possible mismatch between the total income of the owner-occupant and the value of her house. In the presence of such a mismatch, taxpayers with a low ratio total income/value of property may incur in liquidity problems, because of the imperfection in the markets of capital and housing. This argument, however, would justify tax relieves limited to special circumstances, which will occur more frequently within particular categories of taxpayers (old people, retired or unemployed persons etc.).

In the political propaganda for the abolition of IMU on main residences in the last two political elections, the argument was also used that the property of the house is often the result of a long lasting sacrifice of the family in order to accumulate the money necessary for the purchase and 
that this saving has a social value. The reason is not clear, however, why other forms of saving of the households, which can be judged even more socially valuable, do not receive the same consideration in the political arena. In Italy, for example, as in many other countries, the return of the investment in human capital is heavily taxed through the PIT and social contribution. No party has, however, ever tried to win the elections with the proposal of abolishing or alleviating the tax on the returns of the household's investment in education.

The reason of politicians' preference for PT as a tool to gain electoral consensus relies on the special antipathy the taxpayers feel towards the PT, which is well known not only to tax economists, but also to politicians. In the electoral campaign the Berlusconi's slogan has been: "IMU is the tax most hated by Italians". Apparently the PT is the most hated tax everywhere in the world, starting from the countries where it has been at the origin of tax revolts. An increasing stream of literature explains this attitude of taxpayers towards PT with its grater salience in comparison with other forms of taxation (Chetty-Looney-Kroft, 2009; Finkelstein, 2009; CabralHoxby, $2010^{1}$ ).

5. The question whether the local PT can be considered a good benefit tax has long been debated in the literature. The discussion opposing the benefit tax view to the capital tax view has lasted about thirty years ${ }^{2}$. It is not possible here to go back to this discussion, and it is neither necessary, if the interest is on the benefit properties of the PT. In fact a major conclusion of that debate has been that, even accepting the capital tax perspective, the PT maintains "significant benefit aspects in that local tax increases tend to be born by local residents" (Zodrow, 2006 ${ }^{3}$ ).

Two conditions are necessary for a good functioning of the PT as a benefit tax. The first is that benefits from local expenditure and PT capitalize, so that market values of houses can be taken as a measure of the net benefit deriving from local expenditure and taxation. A large amount of empirical literature has provided some evidence of capitalization, but is still far from being conclusive. Studies referring to the Italian case are still few. Considering the expenditure for local transports over the period 2002-2007, a recent study (Bergantino-Porcelli, 2013) offers good empirical evidence supporting the hypothesis of capitalization.

However, a point can be raised whose implications perhaps have not been always fully considered. Even admitting that the PT and the benefit from local capital expenditure do capitalize into the market values of houses, the good functioning of the PT as a benefit tax may be undermined if the values assessed for tax purposes are different from those given by the market and if the two are not positively correlated at least in the short run. This is certainly the case of the Italian ICI/IMU, which is applied to cadastral values that have not been updated for a long time, but just revaluated in absolute terms through fix coefficients applied to different categories of cadastral rent. It can, however, also be the case of countries where a cadastral system does not exist, but nevertheless the values assessed for tax purposes still differ from market values. Alm et al. (2011) has recently shown that in the U.S. the collapse of the housing prices due to the bursting of housing bubble has not produced an equivalent reduction in the PT revenue for local governments. This could happen not only because local governments have increase the millage rates, but also because the decrease in market values are not translated into assessed values.

\footnotetext{
${ }^{1}$ The theme was anticipated by Puviani (1903), an eminent member of the Italian School of Public Finance.

${ }^{2}$ We limit to recall a few among the main contributions: Mieszkowski (1972), Aaron (1974), Musgrave (1974), Bird (1976), Mieszkowski-Zodrow (1989). For a more recent survey of the main results of that debate see Zodrow, 2006.

${ }^{3}$ But see also Bird (1976).
} 
The second condition necessary in order to consider PT a benefit tax is that when houses are rented, the tax is translated from the landlords to the tenants. The tax shifting into higher rents requires well functioning competitive markets for housing. In many countries, instead, the housing market is highly regulated and, where it is not, nevertheless the adjustment of rental contracts to the new market conditions requires time. The tax shifting will probably be confined to the medium and long term.

In conclusion, because of uncertainty about the effective capitalization of net benefits of local expenditure and taxation, on one side, and institutional aspects concerning the actual mechanism of assessment of the PT and the functioning of the housing market, on the other side, doubts can be raised on the accuracy of the PT as a tool for implementing the benefit principle.

6. As mentioned, in Italy the government has recently announced the substitution of the municipal PT with a residence tax (RT). The main difference between the two is that when the dwelling is rented, the PT is paid by the landlords, while the RT is paid by the tenants. Thus the difference stays in the legal incidence of the tax and, if we believe in the traditional theory of tax incidence, this should not matter at all.

Actually in Italy the reasons of such a reform are of a political nature. The change of the PT into a RT is considered an expedient to make the owners who live in their houses to pay some tax, without denying the electoral commitment to abolish IMU on owner-occupied dwellings, taken by one party of the government coalition. However, it is hard to believe that a mere dressing up of the tax could change the attitude of taxpayers towards it. Probably the perception of the tax could change only if the reform could be used also to change the manner the tax is paid. In a very interesting paper Cabral and Hoxby (2010) have investigated the relation between the salience of taxes and the ways they are paid. With reference to the PT they show that salience decreases in case of "tax escrow" that is "when people have their property taxes divided into equally monthly amounts and folded into their monthly mortgage payments". This method of payment of the PT is used in the U.S. by about $31 \%$ of the population.

It is not clear how a similar mechanism could be adopted in different institutional contexts. In any case the system would be limited to households having to repay a mortgage. For the other taxpayers it would remain difficult to envisage an analogous system of payment with a third-party involvement, which could allow hiding the tax within other regular payments as in the case of mortgage. It should also be mentioned "that voters facing a non-benevolent government may wish to keep taxes' salience high even if, as a result, they hate their highly salient taxes" (CabralHoxby, 2010) ${ }^{4}$.

Leaving aside the theme of salience, it can be questioned which could be the difference, if any, between the traditional PT and a RT on economic grounds. In principle, as already mentioned, being the difference between the two taxes only a matter of legal incidence, they should be considered equivalent in economic terms. This is because, as the classical theory of tax incidence has demonstrated, the real burden of the tax is determined by market forces independently of legal incidence. Thus, in order to consider a RT something different from a PT is necessary to assume that legal incidence does matter, because of market imperfections and institutional constraints. If this is the case and we assume that, if the tax is charged to the landlords, they will

\footnotetext{
${ }^{4}$ With reference to the Italian case, Bracco-Porcelli-Redoano (2013) test the hypothesis that political competition, instead of improving efficiency in the provision of local services, may produce a shift form salient taxes to less salient ones.
} 
effectively bear its burden at least in the short run, and that the same thing would happen to the tenants if they are the subject of the tax, the two taxes would have different implications on the ground of equity. Landlords are in general richer than the tenants. In the case of a RT it would then be justified to introduce in the tax design a number of elements in order to take into account ability-to-pay aspects, primarily by graduating the tax rates or allowing for tax relieves according to the level of income of the family living in the house.

On the other side, a RT can be seen as a more accurate tool than a PT for implementing the benefit principle. This holds even if we instead stick to the idea that the burden of the tax is always on the tenants, irrespectively of its legal incidence. For any given increase in the tax/expenditure net benefit and thus for any given increase in the values of houses and in the level of rents, the actual benefit accruing to the family living in the house would depend on a number of circumstances which are not related with the value of the house and the level of the rent. These circumstances would be, instead, related to the characteristics of the family using the house: the number of members of the family, the presence of child, of students, of old people etc. Within a RT it is possible to take these elements into account, while it is not with a PT, which is collected from the landlords.

\section{Conclusions}

In the paper some open issues about the PT have been discussed in the light of the Italian case. The Italian experience confirms the strong negative attitude of the taxpayers towards the PT, which has been extensively discussed in the literature and has been recently explained in terms of the great salience of this tax. Berlusconi's political party has successfully exploited the hate of the taxpayers for the PT in the last two electoral competitions. As a result the government presently in charge is committed to change the design of the tax. It has been announced the adoption of the model of the RT, applied in the U.K. and in France. In principle, according to the economic theory of tax incidence, a RT should produce the same economic effects of a PT. In concrete, however, because of market imperfections and institutional constraints, important differences may arise. While there could be some concerns about the distributive effects of a RT, from the point of view of the benefit principle the RT may offer some advantages respect to the PT.

\section{References}

Alm J., R.D. Buschman, D. L. Sjoquist (2011), Rethinking local government reliance on the property tax, Regional Science and Urban Economics, 41 320-331

Aaron, Henry J. (1974), 'A New View of Property Tax Incidence', 64, American Economic Review, 212-221.

Bergantino A. S., F. Porcelli (2013), Housing market prices: capitalisation of efficiency in local public service provision. An application with data on Italian urban transport related expenditures, Southern Europe Research in Economic Studies, SERIES n. 47, Economics Department, University of Bari 
Bird, Richard M. (1976), "The Incidence of the Property Tax: Old Wine in New Bottles", Canadian Public Policy/Analyse de Politiques, Vol. 2, Supplement: Property Tax Reform, 323-334.

Bracco E., F. Porcelli, M. Redoano (2013), Political Competition, Tax Salience and Accountability: Theory and Some Evidence from Italy, paper presented at IIPF 69th Annual Congress, Taormina, August 22- 25, 2013

Cabral M., C. Hoxby (2010), The Hated Property Tax: Salience, Tax Rates, and Tax Revolts, NBER Working Paper 18514

Chetty, R., A. Looney, K. Kroft (2009), "Salience and Taxation: Theory and Evidence," American Economic Review, 1145-1177

Finkelstein, A, (2009), "EZ-Tax: Tax Salience and Tax Rates," Quarterly Journal of Economics, vol. 124, no.3, pp. 969-1010.

Mieszkowski P. (1972), "The Property Tax. An Excise Tax or a Profits Tax?", Journal of Public Economics, 1(1), pp. 73-96.

Mieszkowski P., G. R. Zodrow (1989), "Taxation and the Tiebout Model: The Differential Effects of Head Taxes, Taxes on Land Rents, and Property Taxes", Journal of Economic Literature, Vol. XXVII, pp. 1098-1146

Ministero dell'Economia e delle Finanze - Dipartimento delle Finanze (2013), Ipotesi di revisione del prelievo sugli immobili, Roma, 7 agosto.

Musgrave, Richard A. (1974), "Is a Property Tax On Housing Regressive?, 64, American Economic Review, Papers and Proceedings, 222-229.

Puviani, A. (1903), Teoria della illusione finanziaria, Milan, Remo Sandron.

Zodrow G.R. (2006), "Who Pays the Property Tax? And What Does Capitalization Tell Us about Who Pays Tax?", Land Lines, April, Vol. 18, 12 